\title{
High Laccase Expression by Trametes versicolor in a Simulated Textile Effluent with Different Carbon Sources and PHs
}

\author{
Cristiane Ottoni ${ }^{1}$, Marta F. Simões ${ }^{2}$, Sara Fernandes ${ }^{3}$, Cledir R. Santos ${ }^{4, *}$ and Nelson Lima ${ }^{5, *}$ \\ 1 Biosciences Institute, São Paulo State University-UNESP, Coastal Campus, São Vicente, \\ São Paulo 11330-900, Brazil; c.a.ottoni@hotmail.com \\ 2 Biology Department, Edge Hill University, St. Helens Road, Lancashire, Ormskirk L39 4QP, UK; \\ simoesm@edgehill.ac.uk \\ 3 Richmond Pharmacology Ltd., St. George's University London, Cranmer Terrace, London SW17 0RE, UK; \\ sarafernandes83@gmail.com \\ 4 Department of Chemical Sciences and Natural Resources, Centro de Excelencia en Investigación \\ Biotecnológica Aplicada al Medio Ambiente (CIBAMA), Scientific and Technological Bioresource \\ Nucleus (BIOREN), Universidad de La Frontera, Temuco 4811-230, Chile \\ 5 CEB-Centre of Biological Engineering, Micoteca da Universidade do Minho, University of Minho, \\ Campus de Gualtar, Braga 4710-057, Portugal \\ * Correspondence: cledir.santos@ufrontera.cl (C.R.S.); nelson@ie.uminho.pt (N.L.); \\ Tel.: +56-452-596-726 (C.R.S.); +351-253-604-403 (N.L.)
}

Academic Editor: Miklas Scholz

Received: 7 June 2016; Accepted: 28 July 2016; Published: 2 August 2016

\begin{abstract}
Textile effluents are highly polluting and have variable and complex compositions. They can be extremely complex, with high salt concentrations and alkaline pHs. A fixed-bed bioreactor was used in the present study to simulate a textile effluent treatment, where the white-rot fungus, Trametes versicolor, efficiently decolourised the azo dye Reactive Black 5 over 28 days. This occurred under high alkaline conditions, which is unusual, but advantageous, for successful decolourisation processes. Active dye decolourisation was maintained by operation in continuous culture. Colour was eliminated during the course of operation and maximum laccase (Lcc) activity $\left(80.2 \mathrm{U} \cdot \mathrm{L}^{-1}\right)$ was detected after glycerol addition to the bioreactor. $L c c 2$ gene expression was evaluated with different carbon sources and $\mathrm{pH}$ values based on reverse transcriptase-PCR (polymerase chain reaction). Glycerol was shown to promote the highest $l c c 2$ expression at $\mathrm{pH} 5.5$, followed by sucrose and then glucose. The highest levels of expression occurred between three and four days, which corroborate the maximum Lcc activity observed for sucrose and glycerol on the bioreactor. These results give new insights into the use of T. versicolor in textile dye wastewater treatment with high pHs.
\end{abstract}

Keywords: alkaline conditions; fixed-bed bioreactor; glycerol; Reactive Black 5; reverse transcriptase -PCR; white-rot fungus

\section{Introduction}

Laccase (Lcc-benzenediol: oxygen oxidoreductase, EC 1.10.3.2) is a ubiquitous enzyme in nature and is widely found in higher plants, fungi, bacteria, insects and lichens [1]. Lcc attracts high interest from environmental biotechnology and industry due to its wide substrate specificity, its high versatility, and its use of molecular oxygen as final electron acceptor [2]. Currently, most studies are focused on production of Lcc by filamentous fungi. The widespread occurrence of highly active Lcc in white-rot fungi (WRF) encourages the search for new sources of these enzymes from these organisms. Lcc can be used for several industrial applications, such as pulp bleaching in the paper industry $[3,4]$, textile dye decolourisation [5,6], and detoxification of environmental pollutants $[3,7,8]$. 
The use of Lcc in textile industry has been increasingly very fast due to its ability to bleach textiles, and biological treatments involving Lcc seems to be an attractive solution mainly because most existing treatments (e.g., coagulation/flocculation, adsorption, ion exchange, and electrochemical methods) of dye wastewater utilize ineffective and uneconomical processes [9]. Recently, Ling et al. [10] reported the decolourisation of synthetic dyes (Bromothymol Blue, Evans Blue, Fuchsin Basic, Malachite Green, Methylene Blue and Reactive Brilliant Blue R) using $0.5 \mathrm{U} \cdot \mathrm{mL}^{-1}$ purified Lcc from the WRF Trametes sp. LAC-01. Chairin et al. [11] also reported the decolourisation of synthetic dyes (Acridine Orange, Bromophenol Blue, Congo Red, Methyl Orange, Reactive Black 5 (RB5) and Remazol Brilliant Blue R) using $0.45 \mathrm{U} \cdot \mathrm{mL}^{-1}$ purified Lcc from the WRF Trametes polyzona. In a different study, decolourisation of RB5 was optimised using crude Lcc from the WRF Trametes pubescens with the mediator 1-hydroxybenzotriazole (HBT) [12]. The authors obtained maximum decolourisation of $150 \mathrm{mg} \cdot \mathrm{L}^{-1} \mathrm{RB} 5$ (60\% in $20 \mathrm{~min}$ ) with $1.17 \mathrm{mM} \mathrm{HBT}$ and $0.5 \mathrm{U} \cdot \mathrm{mL}^{-1} \mathrm{Lcc}$. The high efficient capability of T. pubescens to decolourise RB5, in successive batches, when immobilised on stainless steel sponges in a fixed-bed bioreactor was also described by Enayatzamir et al. [13]. The main enzyme involved was Lcc at pH 4.5. However, a decrease in activity was reported in the final stages of the cultivation probably due to high $\mathrm{pH}$ values (8-9).

Textile dye wastewater is notorious for having a strong colour, with high Chemical Oxygen Demand (COD), high salt concentrations, and high $\mathrm{pH}$ [14]. Many studies do not take into account these peculiar parameters, which affect the activity of the degrading enzymes. Fungal Lcc activity at basic $\mathrm{pH}$ values are highly desirable for the decolourisation of recalcitrant dyes [5]. Therefore, the search and use of new fungal Lcc with high activity at $\mathrm{pH}>7.0$ are of particular interest [15-17].

Industrial effluents have variable composition, and in many cases are extremely complex. Typically, they have few nutrients when compared to laboratory culture media and, therefore, a better knowledge on the nutrients, in particular carbon and nitrogen sources required in industrial effluents for effective biodegradation, is highly desirable. Glucose is the most widely used carbon source in fungal growth media and is effective for the expression of many enzymes. However, other carbon sources can also be effective, e.g., sucrose, fructose, glycerol, and starch [18]. Myasoedova et al. [19] described the influence of carbohydrates in regulating $l c c$ expression synthesised by WRF.

$L c c$ gene transcriptional regulation is influenced by several different factors (e.g., media composition and culture conditions), and this influence has been demonstrated in many WRF. In most reports, $l c c$ expression is described as being regulated by several different factors, often acting synergistically [20]. In addition, the selection of microorganisms and culture media allows for the design of cost-effective processes [21,22]. According to several authors [23-25], expression of this enzyme can be facilitated by regulation with metal ions, lignin related aromatic compounds and derivatives, and carbon and nitrogen. In this context, the current study aims to investigate the capability of T. versicolor to decolourise RB5 under alkaline conditions in a fixed-bed bioreactor and evaluate the effect of different carbon sources and $\mathrm{pH}$ for $l c c 2$ expression.

\section{Materials and Methods}

\subsection{Fungus and Medium Composition}

Trametes versicolor MUM 04.100 was obtained from the Portuguese Culture Collection Micoteca da Universidade do Minho (MUM), Braga, Portugal. This strain grown on BR5 under alkaline conditions, as previously reported by Ottoni et al. [5]. The strain was maintained on Tap Water Agar-cellulose plates (15 g.L $\mathrm{L}^{-1}$ TWA-cellulose, Oxoid Technical Agar No. 3 (Hampshire, UK), in tap water supplemented with a Whatman grade 4 filter paper strip) and subcultured on a monthly basis. Liquid culture medium (LCM) was composed by $5.0 \mathrm{~g} \cdot \mathrm{L}^{-1}$ sucrose, $0.5 \mathrm{~g} \cdot \mathrm{L}^{-1}$ ammonium sulphate (Sigma, St. Louis, MO, USA), $1.7 \mathrm{~g} \cdot \mathrm{L}^{-1}$ yeast nitrogen base (YNB) amino acids and ammonium sulphate free (Sigma), $1.0 \mathrm{~g} \cdot \mathrm{L}^{-1}$ L-asparagine (Sigma) and $0.1 \mathrm{~g} \cdot \mathrm{L}^{-1} \mathrm{RB}$. The initial $\mathrm{pH}$ of the LCM was adjusted to $\mathrm{pH}$ 9.5, value set 
based on previous research works [5,6], using $1 \mathrm{M} \mathrm{NaOH}$ aqueous solution. The pre-adaption medium (PAM) consisted in LCM containing $15 \mathrm{~g} \cdot \mathrm{L}^{-1}$ Oxoid Technical Agar No. 3.

\subsection{Culture Conditions}

\subsubsection{Decolourisation of RB5 in a Fixed-Bed Bioreactor}

Reactive Black 5 (RB5), also known as Remazol Black B, is a textile diazo blue dye (absorbance $\lambda_{\max }$ at $592 \mathrm{~nm}$ ) with a molecular structure represented in Figure 1; a chemical formula of $\mathrm{C}_{26} \mathrm{H}_{21} \mathrm{~N}_{5} \mathrm{Na}_{4} \mathrm{O}_{19} \mathrm{~S}_{6}$ and molecular weight of $991.82 \mathrm{~g} \cdot \mathrm{mol}^{-1}$. The Colour Index (CI) is 20505 and the Chemical Abstracts Service (CAS) numbers are 12225-25-1 and 17095-24-8. RB5 compound from Sigma-Aldrich No. 306452 (Steinheim, Germany) was used in aqueous solution.

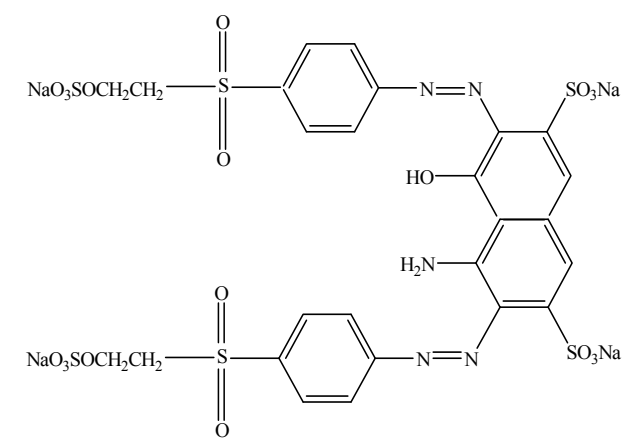

Figure 1. Molecular structure of Reactive Black 5 diazo compound with two N double bound N bounds.

The design of the bioreactor in this research was influenced by the design of other bioreactors and fungi used previously for Lcc enzyme production, dye decolourisation, or textile wastewater treatment [26-28].

Continuous RB5 decolourisation was carried out in a ca. $300 \mathrm{~mL}$ fixed-bed bioreactor (Figure 2) using free T. versicolor cells.

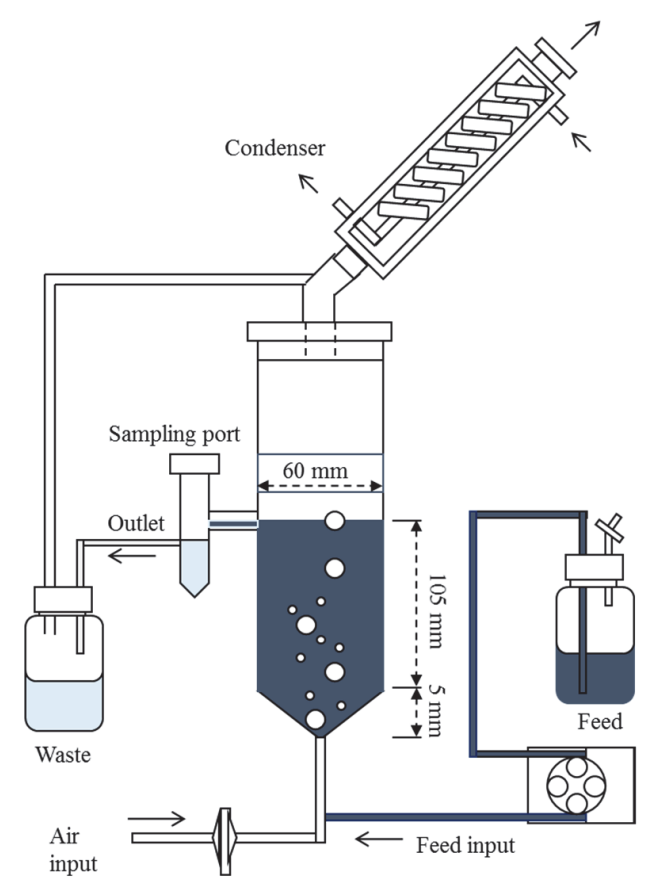

Figure 2. Diagram of the fixed-bed reactor used in the present study. The elements are not in scale. 
The bioreactor had a working volume of $260 \mathrm{~mL}$ and was run continuously via a peristaltic pump and with continuous agitation provided by the aeration at room temperature (ca. $30^{\circ} \mathrm{C}$ ) without $\mathrm{pH}$ control. Aeration was established by the agitation rate that avoided excessive foam. Thirteen plugs, $8 \mathrm{~mm}$ in diameter, cut with a sterile cork-borer from the periphery of a 7-day-old colony grown on PAM plates, were used as the inoculum. The plugs were grown in a $500 \mathrm{~mL}$ Erlenmeyer flask containing $260 \mathrm{~mL}$ of LCM and incubated for 9 days in a Certomat rotary shaker $(150 \mathrm{rpm})$ at $30^{\circ} \mathrm{C}$. The biomass was vacuum-filtered and transferred into the bioreactor under aseptic conditions. The bioreactor was loaded with fresh LCM and operated in batch mode until total decolourisation. Afterwards, it started to be continuously fed with an aqueous solution of RB5 $\left(0.1 \mathrm{~g} \cdot \mathrm{L}^{-1}\right.$ at $\left.\mathrm{pH} 9.5\right)$ with a mass fixed flow rate of $2.14 \mathrm{mg} \cdot \mathrm{day}^{-1}$ and a hydraulic retention time of 7.14 days. During the time course of decolourisation when $85 \%$ or less was achieved pulses of $5 \mathrm{~g} \cdot \mathrm{L}^{-1}$ sucrose or glycerol final concentration were made at different times in order to maintain fungal metabolism for an extended fermentation time period. The continuous fermentation was run without external nitrogen source. The dye decolourisation and enzymatic activity were assessed daily.

\subsubsection{Carbon Source Monitoring}

Sucrose concentrations were monitored by high performance liquid chromatography (Jasco AS-950, Tokyo, Japan). The detector used was a refractive index (Jasco RI-830, Tokyo, Japan). The column used was a MetaCarb $67 \mathrm{H}(300 \times 6.5 \mathrm{~mm})$ and its internal temperature was adjusted to $60{ }^{\circ} \mathrm{C}$. The mobile phase used was $0.005 \mathrm{~mol} \cdot \mathrm{L}^{-1}$ of an aqueous solution of $\mathrm{H}_{2} \mathrm{SO}_{4}$ at a flow rate of $0.7 \mathrm{~mL} \cdot \mathrm{min}^{-1}$. Samples were injected in a volume of $20 \mu \mathrm{L}$.

In order to determine the sucrose concentrations, a standard curve was created where the initial sucrose concentration in LCM corresponded to $100 \%$. All samples analysed were collected and monitored daily.

\subsection{Influence of Different Carbon Sources on Expression of Lcc Gene}

\subsubsection{Genomic DNA Isolation, Sequencing and Sequence Analysis}

Five plugs, $8 \mathrm{~mm}$ in diameter were cut with a sterile cork-borer, from the periphery of a 7-day-old colony of TWA-cellulose and inoculated in $250 \mathrm{~mL}$ Erlenmeyer flasks containing $100 \mathrm{~mL}$ of Glucose Yeast Peptone (GYP, $3 \mathrm{~g} \cdot \mathrm{L}^{-1}$ malt extract, $10.0 \mathrm{~g} \cdot \mathrm{L}^{-1}$ glucose, $3 \mathrm{~g} \cdot \mathrm{L}^{-1}$ yeast extract and $5 \mathrm{~g} \cdot \mathrm{L}^{-1}$ peptone). These were incubated on a Certomat rotary shaker for 6 days at $30^{\circ} \mathrm{C}$ and $150 \mathrm{rpm}$. Mycelium of T. versicolor was frozen and used for genomic DNA isolation [29]. Primers were designed, based on the sequence analysis of $l c c 2$ gene (GenBank accession No. Y18012.1; 5'-ATGTCGAGGTTTCACTCTCTTC-3') [30] and the housekeeping gene $\beta$-tubulin (GenBank accession No. AY944858.1; 5'-CGGTGAGAGGCGTCGGACAC-3') for T. versicolor. The DNA amplification was performed using a thermocycler (MyCycler ${ }^{\mathrm{TM}}$, BioRad, Hercules, CA, USA).

Reaction conditions for PCR amplification consisted of an initial denaturation at $94{ }^{\circ} \mathrm{C}$ for $2 \mathrm{~min}$, 35 cycles of denaturation at $94{ }^{\circ} \mathrm{C}$ for $0.75 \mathrm{~min}$, annealing at $49-60{ }^{\circ} \mathrm{C}$ (depending on the primers) for $0.5 \mathrm{~min}$ and extension at $72{ }^{\circ} \mathrm{C}$ for $2 \mathrm{~min}$, with a final extension of $4 \mathrm{~min}$ at $72{ }^{\circ} \mathrm{C}$. GoTaq DNA polymerase (Promega, Foster, CA, USA) was used in the PCR reactions. PCR products were separated by agarose gel electrophoresis and the correspondent bands for $l c c 2$ and $\beta$-tubulin purified using the (Qiagen, Hilden, Germany). DNA sequencing was conducted in both directions by Eurofins MWG Operon (Ebersberg, Germany). A homology search was conducted with the laccase sequence from T. versicolor using protein BLAST (Basic Local Alignment Search Tool) [31] and for comparison purposes ClustalW was used to create multiple sequence alignments [32].

\subsubsection{RNA Extraction and RT-PCR}

Five plugs, $8 \mathrm{~mm}$ in diameter were cut with a sterile cork-borer from the periphery of a 7-day-old colony of T. versicolor grown in PAM. The plugs were inoculated in a $250 \mathrm{~mL}$ Erlenmeyer flask 
containing $100 \mathrm{~mL}$ GYP and incubated on a Certomat rotary shaker for 5 days at $30^{\circ} \mathrm{C}$ and $150 \mathrm{rpm}$. Biomass was then retrieved and carefully washed three times with $150 \mathrm{~mL}$ sterile water using vacuum filtration under sterile conditions. From that biomass, ca. $1 \mathrm{~g}$ was transferred into 36 Erlenmeyer flasks, each containing $100 \mathrm{~mL}$ of the LCM (Section 2.1) with $5 \mathrm{~g} \cdot \mathrm{L}^{-1}$ of carbon source and the following conditions: Glucose, sucrose and glycerol, with $\mathrm{pH} 9.5$ and without $\mathrm{pH}$ adjustment. The Erlenmeyer flasks were then incubated for a period of two, up to six, days at $30{ }^{\circ} \mathrm{C}$ and $150 \mathrm{rpm}$. For each condition, total RNA was extracted according to Chomczynski and Sacchi [33]. The cDNA syntheses were performed with SuperScript ${ }^{\mathrm{TM}}$ III Reverse Transcriptase 18080-093 kit (Invitrogen, Carlsbad, CA, USA). PCR amplifications were performed, as described in the previous section, with $52{ }^{\circ} \mathrm{C}$ as the optimal annealing temperature for $l c c 2$. PCR products were separated by electrophoresis. Using Gel Doc XR System (Bio-Rad, Hercules, CA, USA), it was possible to visualise the gel and document images. The analysis for the quantification of expression levels of the gene of interest was performed using densitometry. The documented images of amplifications were treated with the support of the program Image J 1.44f [34]. Results were normalised by densitometry according to the constitutive gene expression of $\beta$-tubulin. Therefore, it was possible to establish the ratio between the lcc 2 gene expression relative to $\beta$-tubulin under different conditions, and the results are presented in arbitrary units.

\subsection{Analytical Methods}

During the experiment, the dye concentration was determined, as previously described by Ottoni et al. [5], using spectrophotometry (190 to $900 \mathrm{~nm}$ ), and an additional control was assayed with autoclaved fungal biomass to evaluate the contribution of the fungal cell walls to dye adsorption at the maximum wavelength $\left(\lambda_{\max }\right)$ of the RB5. The absorbance value of the LCM containing the initial concentration of dye corresponds to $100 \%$ of dye. The spectra were obtained from $5 \mathrm{~mL}$ of supernatant samples. $\mathrm{pH}$ values were recorded for each sample.

\subsection{Enzymatic Assays}

Laccase activities were determined at room temperature by oxidation of $90 \mu \mathrm{L}$ of a $0.11 \mathrm{mM}$ solution of syringaldazine (4-hydroxy-3,5-dimethoxybenzaldehyde azine, Sigma-Aldrich) in ethanol absolute (Merck, Darmstadt, Germany), $10 \mu \mathrm{L}$ aliquots of supernatant samples, $200 \mu \mathrm{L}$ citric acid/sodium hydrogen phosphate buffer solution ( $\mathrm{pH}$ 6.0) mixed in a total volume of $300 \mu \mathrm{L}$ [35]. The oxidation of syringaldazine was determined at $525 \mathrm{~nm}$ with an extinction coefficient $\varepsilon_{525 \mathrm{~nm}}=65,000 \mathrm{M}^{-1} \cdot \mathrm{cm}^{-1}$ using a UV/Vis spectrophotometer (Jasco 560$)$. The same reaction mixtures, but with boiled supernatant samples, were used as blanks for each of the enzymatic activity assays. The amount of the enzyme responsible for the change of 0.01 of absorbance per minute, under the assay conditions, was defined as one unit (U) of enzyme activity; additionally, all enzyme activity values were expressed as units per litre $\left(\mathrm{U} \cdot \mathrm{L}^{-1}\right)$. In order to evaluate the adsorption of the dye on the fungal mass during the reactions, the samples were collected daily and filtered according to previous studies [6,35].

\section{Results and Discussion}

\subsection{Decolourisation of RB5}

Maximum Lcc activities were observed on day $6\left(60.4 \mathrm{U} \cdot \mathrm{L}^{-1}\right), 12\left(52.1 \mathrm{U} \cdot \mathrm{L}^{-1}\right), 17\left(62.2 \mathrm{U} \cdot \mathrm{L}^{-1}\right)$ and $23\left(80.2 \mathrm{U} \cdot \mathrm{L}^{-1}\right)$, with a concomitant dye decolourisation of $99 \%, 97.5 \%, 100 \%$, and $100 \%$, respectively (Figure 3). These results show high dye decolourisation three to four days after each addition of the carbon sources. Moreover, high Lcc activity was related to the decolourisation process of RB5 and biomass growth. The nitrogen was a limited factor during the fermentation, confirming, what is generally accepted, that a high carbon-to-nitrogen ratio is required for Lcc production in WRF. The biomass purges were done at days 11,17 , and 24 to maintain the aeration and the bioreactor operational. Other enzymes were analysed (i.e., manganese peroxidase, lignin peroxidase, glyoxal 
oxidase, proteases, phenoloxidase), but without relevant activity (data not shown). No significant adsorption of the dye on the fungal biomass was detected.

Peaks in Lcc activity ranged from $50.9 \mathrm{U} \cdot \mathrm{L}^{-1}$ to $80.2 \mathrm{U} \cdot \mathrm{L}^{-1}$ depending on the carbon source used. Whenever a reduction $(<85 \%)$ in the decolourisation rate was observed, a new carbon source pulse was made. When glycerol was used, the maximum value $\left(80.2 \mathrm{U} \cdot \mathrm{L}^{-1}\right)$ of Lcc activity was achieved together with a decolourising rate of $100 \%$ on days 23 and 25. Kanwal and Reddy [36] evaluated the effect of different carbon sources on ligninolytic activity of Morchella crassipes and concluded that Lcc activity variation depended on the carbon source used. Furthermore, and in agreement with the findings on this study, glycerol was described as a good inducer for the production of Lcc using Trametes hirsuta [26] and Pleurotus ostreatus [37].

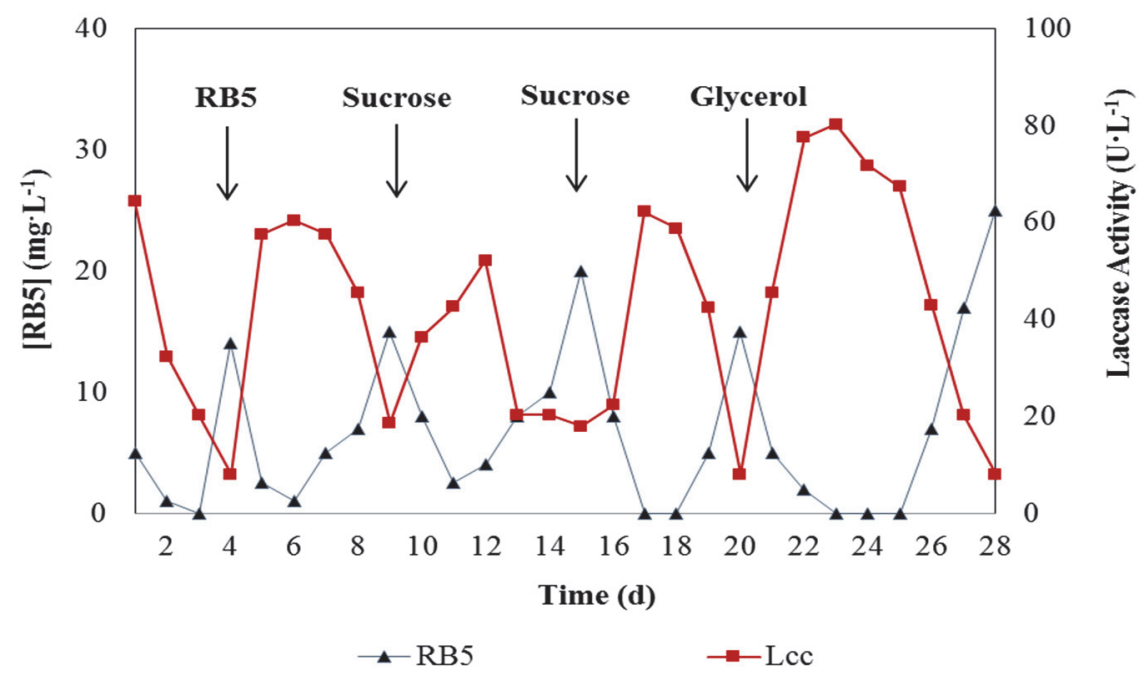

Figure 3. Time course of Reactive Black $5\left(\mathrm{RB} 5,0.1 \mathrm{~g} \cdot \mathrm{L}^{-1}\right.$ at $\left.\mathrm{pH} 9.5\right)$ concentration and Lcc activity using T. versicolor. The bioreactor operated in batch mode with LCM until total decolourisation and was then continuously fed with RB5 at day 4 . Rows indicated when the pulses of different carbon sources at concentration of $5 \mathrm{~g} \cdot \mathrm{L}^{-1}$ were added to the RB5 solution at days 9, 15 and 20.

Ottoni et al. [6] used the same strain as in the present study, and extreme saline and alkaline conditions, and found an optimal Lcc activity of $119.8 \mathrm{U} \cdot \mathrm{L}^{-1}$ was obtained for glycerol when compared to $60.0 \mathrm{U} \cdot \mathrm{L}^{-1}$ obtained for sucrose. Rodríguez Couto et al. [26] recorded an activity of $19,394 \mathrm{U} \cdot \mathrm{L}^{-1}$ laccase from T. hirsta after glycerol addition. Kachlishvili et al. [38], among seven carbon sources studied found, after glucose, glycerol as good carbon source to increasing the Lcc activity in Cerrena unicolor. In a co-culture process, Li et al. [39] reported to Ganoderma lucidum that, under the condition of glucose deprivation, the use of glycerol as a secondary carbon source produced by the yeast Candida sp. HSD07An leads to the overproduction of Lcc.

Most of the studies published are performed in acidic conditions despite textile effluents being alkaline. Enayatzamir et al. [13] reported the ability of T. pubescens to decolourise RB5 in a fixed-bed reactor at $\mathrm{pH}$ 4.5. Furthermore, Baccar et al. [27] found good bleaching results when using T. versicolor at $\mathrm{pH} 4.5$ to decolourise Dycem Black TTO dye used in the tanning industry. The strain used decolourised $94 \%$ of the dye under agitation in Erlenmeyer flasks, and over $86 \%$ in a bioreactor and found that Lcc was the principal enzyme involved. On the other hand, Ottoni et al. [5,6] reported decolourisation of RB5 under alkaline conditions using the same strain as in the present study.

The decolourisation rate observed (Figure 3) was influenced by the addition of carbon sources, confirming the results of Pakshirajan and Kheria [40]. According to their data, $5.0 \mathrm{~g} \cdot \mathrm{L}^{-1}$ glucose led to optimal decolourisation of $80 \%$. In contrast, no carbon source reduced the decolourisation to $53 \%$. Osma et al. [2] detected maximum Lcc activities of $51 \mathrm{U} \cdot \mathrm{L}^{-1}, 89 \mathrm{U} \cdot \mathrm{L}^{-1}$ and $228 \mathrm{U} \cdot \mathrm{L}^{-1}$ using T. pubescens, when glucose, glycerol, and mandarin peelings, as carbon sources, respectively, were employed. 
Borchert and Libra [41] analysed decolourisation rates of synthetic dyes by free cells of T. versicolor at $\mathrm{pH}$ 5.0, and suggested the possibility of reusing the cell culture for a long time without decreasing the activity of extracellular enzymes. This was confirmed by the experiments performed in this present study, where decolourisation was observed until the end of the assay (Figure 3).

\subsection{Gene Expression of lcc2 Gene}

A variety of reports highlighting the inducing effect of carbon sources in the decolourisation of dyes are available [10,19,24,25,42]. Figure 4 shows the results obtained for the expression of $l c c 2$ using different carbon sources and the initial 9.5 and final $5.5 \mathrm{pHs}$ obtained during the fermentation study. To perform this, oligonucleotide primers, based on existing T. versicolor laccase gene (GenBank accession No. Y18012.1), were used and a specific band of $1563 \mathrm{bp}$ was amplified from T. versicolor chromosomal DNA. Sequence analysis of the products revealed 100\% identity with the laccase Y18012.1 and high similarity with other $T$. versicolor laccase sequences, indicating that $T$. versicolor laccase gene was successfully cloned. The transcriptional regulation of T. versicolor lcc 2 was studied by RT-PCR analysis during growth on different carbon sources.

The $l c c 2$ gene was expressed at different levels in the time period between three and six days, with the highest values occurring between three and four days, with their subsequent reduction (Figure 4a). In contrast, at the 2nd day of incubation no $l c c 2$ gene was expressed for any conditions studied. Trametes versicolor MUM 04.100 showed a higher expression of this enzyme when using glycerol as a carbon source, followed by sucrose and then glucose. Glucose is not the optimal substrate to lcc2 expression, which is corroborated by Rodríguez Couto et al. [26] for Lcc activity for T. hirsuta and Osma et al. [2] for T. pubescens.

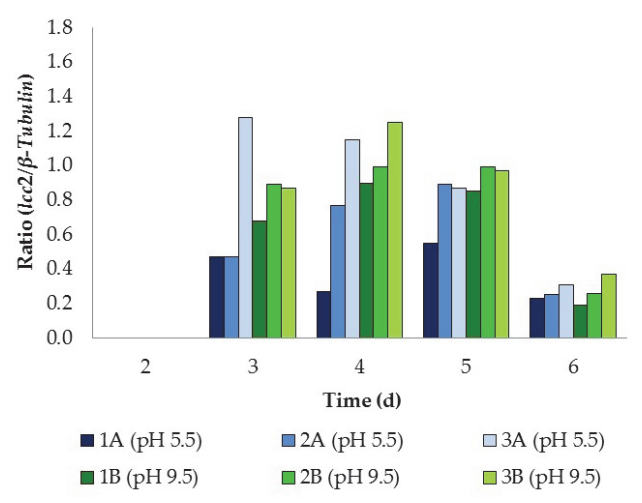

(a)

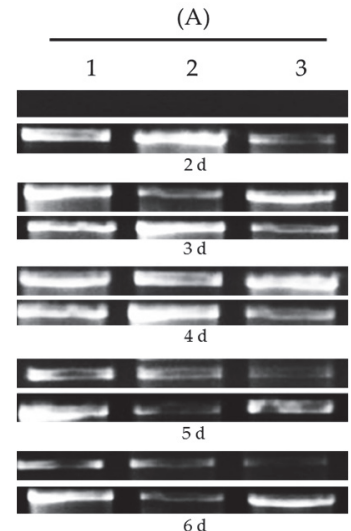

$6 \mathrm{~d}$

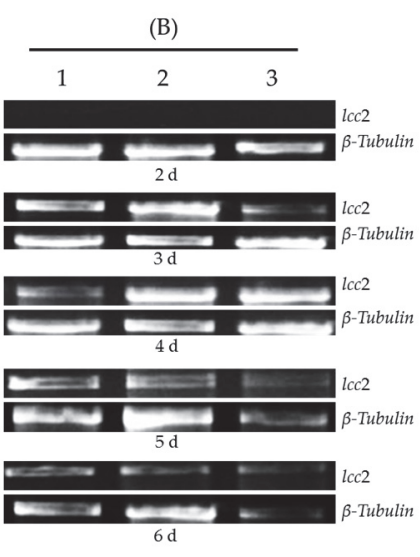

(b)

Figure 4. Detection of $l c c 2$ gene expression by the strain T. versicolor MUM 04.100 under different culture conditions in batch shake flasks: (a) by densitometry with arbitrary unites based on the (b) RT-PCR transcripts. (A) LCM with initial pH 5.5; (B) LCM with initial pH 9.5 and carbon sources evaluated, (1) glucose, (2) sucrose, (3) glycerol.

The highest $l c c 2$ expression (1.28) was detected for glycerol at $\mathrm{pH} 5.5$ after three days of incubation (Figure 4). However, $\mathrm{pH} 9.5$ was generally more favorable than the acidic $\mathrm{pH}$; however, it is known that, after three days, due a weak buffer condition when compared to the real textile effluents, the high $\mathrm{pH}$ can drop down to ca. 4.5-5.5, which is similar to the other $\mathrm{pH}$ studied. There was an abrupt reduction in the $l c c 2$ expression on day 6, coinciding with the reduction Lcc activity in the bioreactor (see Figure 3). According to Baldrian [43], fungal Lcc activity typically exhibits an optimum $\mathrm{pH}$ in acidic conditions; however, our results indicate that increased expression of the enzyme was obtained under alkaline conditions. Similar results were obtained elsewhere with Trametes trogii [44] and Cerrena unicolor [45], where Lcc was found to be stable at high $\mathrm{pH}$ values. Additionally, Liu et al. [46] developed a mutant 
Lac3T93, considered an efficient catalyst, with greatly increased enzymatic activity and decolourisation capacity under alkaline conditions. They found that the $\mathrm{pH} 8.0$ for dye degradation was similar when using Lac3T93 or CotA-laccase from Bacillus subtilis ( $\mathrm{pH}$ 8.0-9.0), but higher than for bacterial laccases (pH 5.0-7.5). Recently, Andriani et al. [47] described a higher Lcc expression by Bjerkandera adusta at $\mathrm{pH}$ 8.2. In addition, Guan et al. [48] also noticed, when testing a recombinant purified Lcc, that it was highly stable at alkaline $\mathrm{pH}$ and high temperatures.

The $\mathrm{pH}$ of the medium was only adjusted to 9.5 at the beginning of the assay employed herein and at the end of the assay the $\mathrm{pH}$ of the medium varied between 4.5 and 5.0. Nevertheless, T. versicolor MUM 04.100 was able to express $l c c 2$ under alkaline conditions (Figure 4). This finding corroborates previous studies $[5,6]$, which report good Lcc performance under alkaline conditions for the same strain.

\section{Conclusions}

The present study demonstrates that using T. versicolor MUM 04.100 under alkaline conditions allows for the decolourisation of RB5, ranging from $80 \%$ to $100 \%$. Glycerol was found to be an optimal carbon source for the strain, making it an attractive alternative source of $l c c 2$ expression and providing a good basis for further evaluation studies on alkaline conditions, and the mechanisms and metabolic intermediates that are formed from RB5.

Acknowledgments: Cledir R. Santos thanks to the Universidad de La Frontera (Temuco, Chile) for the partial funding from both the Project DIUFRO DI16-0135 and the Doctoral Programme in Science of Natural Resources. This study was also supported by the Portuguese Foundation for Science and Technology (FCT) under the scope of the strategic funding of UID/BIO/04469/2013 unit and COMPETE 2020 (POCI-01-0145-FEDER-006684) and BioTecNorte operation (NORTE-01-0145-FEDER-000004) funded by European Regional Development Fund under the scope of Norte2020-Programa Operacional Regional do Norte.

Author Contributions: Cristiane Ottoni, Cledir R. Santos and Nelson Lima conceived and designed the experiments; Cristiane Ottoni, Sara Fernandes and Marta F. Simões performed the experiments; Cristiane Ottoni and Marta F. Simões analysed the data; Cristiane Ottoni, Marta F. Simões, Cledir R. Santos and Nelson Lima wrote the paper. All authors discussed the results and commented on the manuscript.

Conflicts of Interest: The authors declare no conflict of interest.

\section{References}

1. Kocyigit, A.; Pazarbasi, M.B.; Yasa, Y.; Ozdemir, G.; Karaboz, I. Production of laccase from Trametes trogii TEM H2: A newly isolated white-rot fungus by air sampling. J. Basic Microbiol. 2012, 52, 661-669. [CrossRef] [PubMed]

2. Osma, J.F.; Toca-Herrera, J.L.; Rodríguez-Couto, S. Cost analysis in laccase production. J. Environ. Manag. 2011, 92, 2907-2912. [CrossRef] [PubMed]

3. Wang, Q.; Jahan, M.S.; Liu, S.; Miao, Q.; Ni, Y. Lignin removal enhancement from prehydrolysis liquor of kraft-based dissolving pulp production by laccase-induced polymerization. Bioresour. Technol. 2014, 164, 380-385. [CrossRef] [PubMed]

4. Singh, G.; Kaur, K.; Puri, S.; Sharma, P. Critical factors affecting laccase-mediated biobleaching of pulp in paper industry. Appl. Microbiol. Biotechnol. 2015, 99, 155-164. [CrossRef] [PubMed]

5. Ottoni, C.A.; Santos, C.; Kozakiewicz, Z.; Lima, N. White-rot fungi capable of decolourising textile dyes under alkaline conditions. Folia Microbiol. 2013, 58, 187-193. [CrossRef] [PubMed]

6. Ottoni, C.; Lima, L.; Santos, C.; Lima, N. Effect of different carbon sources on decolourisation of an industrial textile dye under alkaline-saline conditions. Curr. Microbiol. 2014, 68, 53-58. [CrossRef] [PubMed]

7. Khlifi, R.; Belbahri, L.; Woodward, S.; Ellouz, M.; Dhouib, A.; Sayadi, S.; Mechichi, T. Decolourization and detoxification of textile industry wastewater by the laccase-mediator system. J. Hazard. Mater. 2010, 175, 802-808. [CrossRef] [PubMed]

8. Bao, S.; Teng, Z.; Ding, S. Heterologous expression and characterization of a novel laccase isoenzyme with dyes decolorization potential from Coprinus comatus. Mol. Biol. Rep. 2013, 40, 1927-1936. [CrossRef] [PubMed]

9. Zhu, M.J.; Zhu, F.; Du, G.Q.; Zhang, H.X.; Wang, T.B.; Ng, T.B. Purification a laccase exhibiting dye decolorizing ability from an edible mushroom Russula virescens. Int. Biodeter. Biodegr. 2013, 82, 33-39. [CrossRef] 
10. Ling, Z.R.; Wang, S.S.; Zhu, M.J.; Ning, Y.J.; Wang, S.N.; Li, B.; Yang, A.Z.; Zhang, G.Q.; Zhao, X.M. An extracellular laccase with potent dye decolorizing ability from white rot fungus Trametes sp. LAC-01. Int. J. Biol. Macromol. 2015, 81, 785-793. [CrossRef] [PubMed]

11. Chairin, T.; Nitheranont, T.; Watanabe, A.; Asada, Y.; Khanongnuch, C.; Lumyong, S. Biodegradation of bisphenol A and decolorization of synthetic dyes by laccase from white-rot fungus, Trametes polyzona. Appl. Biochem. Biotechnol. 2013, 169, 539-545. [CrossRef] [PubMed]

12. Roriz, M.S.; Osma, J.F.; Teixeira, J.A.; Couto, S.R. Application of response surface methodological approach to optimise Reactive Black 5 decolouration by crude laccase from Trametes pubescens. J. Hazard. Mater. 2009, 169, 691-696. [CrossRef] [PubMed]

13. Enayatzamir, K.; Alikhani, H.A.; Couto, S.R. Simultaneous production of laccase and decolouration of the diazo dye Reactive Black 5 in fixed-bed bioreactor. J. Hazard. Mater. 2009, 164, 296-300. [CrossRef] [PubMed]

14. Ibrahim, D.S.; Anand, A.P.; Muthukrishnaraj, A.; Thilakavathi, R.; Balasubramanian, N. In situ electro-catalytic treatment of a Reactive Golden Yellow HER synthetic dye effluent. J. Environ. Chem. Eng. 2013, 1, 2-8. [CrossRef]

15. Daâssi, D.; Zouari-Mechichi, H.; Prieto, A.; Martínez, M.J.; Nasri, M.; Mechichi, T. Purification and biochemical characterization of a new alkali-stable laccase from Trametes sp. isolated in Tunisia: Role of the enzyme in olive mill waste water treatment. World J. Microbiol. Biotech. 2013, 29, 2145-2155. [CrossRef] [PubMed]

16. Torres-Salas, P.; Mate, D.M.; Ghazi, I.; Plou, F.J.; Ballesteros, A.O.; Alcalde, M. Widening the pH activity profile of a fungal laccase by directed evolution. ChemBioChem 2013, 14, 934-937. [CrossRef] [PubMed]

17. Zhuo, R.; He, F.; Zhang, X.; Yang, Y. Characterization of a yeast recombinant laccase rLAC-EN3-1 and its application in decolorizing synthetic dye with the coexistence of metal ions and organic solvents. Biochem. Eng. J. 2015, 93, 63-72. [CrossRef]

18. Ma, L.; Zhuo, R.; Liu, H.; Yu, D.; Jiang, M.; Zhang, X.; Yang, Y. Efficient decolorization and detoxification of the sulfonated azo dye Reactive Orange 16 and simulated textile wastewater containing Reactive Orange 16 by the white-rot fungus Ganoderma sp. En3 isolated from the forest of Tzu-chin Mountain in China. Biochem. Eng. J. 2014, 82, 1-9. [CrossRef]

19. Myasoedova, N.M.; Gasanov, N.B.; Chernykh, A.M.; Kolomytseva, M.P.; Golovleva, L.A. Selective regulation of laccase isoform production by the Lentinus strigosus 1566 fungus. Appl. Biochem. Microbiol. 2015, 51, 222-229. [CrossRef]

20. Giardina, P.; Faraco, V.; Pezzella, C.; Piscitelli, A.; Vanhulle, S.; Sannia, G. Laccases: A never-ending story. Cell. Mol. Life Sci. 2010, 67, 369-385. [CrossRef] [PubMed]

21. Böhmer, U.; Frömmel, S.; Bley, T.; Müller, M.; Frankenfeld, K.; Miethe, P. Solid-state fermentation of lignocellulotic materials for the production of enzymes by the white-rot fungus Trametes hirsuta in a modular bioreactor. Eng. Life Sci. 2011, 11, 395-401. [CrossRef]

22. Tišma, M.; Žnidaršič-Plazl, P.; Vasić-Rački, Đ.; Zelić, B. Optimization of laccase production by Trametes versicolor cultivated on industrial waste. Appl. Biochem. Biotechnol. 2012, 166, 36-46. [CrossRef] [PubMed]

23. Zhuo, R.; Ma, L.; Fan, F.; Gong, Y.; Wan, X.; Jiang, M.; Zhang, X.; Yang, Y. Decolorization of different dyes by a newly isolated white-rot fungi strain Ganoderma sp. En3 and cloning and functional analysis of its laccase gene. J. Hazard. Mater. 2011, 192, 855-873. [CrossRef] [PubMed]

24. Parenti, A.; Muguerza, E.; Iroz, A.R.; Omarini, A.; Conde, E.; Alfaro, E.; Castanera, R.; Santoyo, F.; Ramírez, L.; Pisabarro, A.G. Induction of laccase activity in the white rot fungus Pleurotus ostreatus using water polluted with wheat straw extracts. Bioresour. Technol. 2013, 133, 142-149. [CrossRef] [PubMed]

25. Passarini, M.R.Z.; Ottoni, C.A.; Santos, C.; Lima, N.; Sette, L.D. Induction, expression and characterisation of laccase genes from the marine-derived fungal strains Nigrospora sp. CBMAI 1328 and Arthopyrenia sp. CBMAI 1330. AMB Express 2015, 5, 19. [CrossRef] [PubMed]

26. Rodríguez Couto, S.; Rodrígues, A.; Paterson, R.R.M.; Lima, N.; Teixeira, J.A. Laccase activity from the fungus Trametes hirsuta using an air-lift bioreactor. Lett. Appl. Microbiol. 2006, 42, 612-616.

27. Baccar, R.; Blánquez, P.; Bouzida, J.; Feki, M.; Attiya, H.; Sarrà, M. Decolorization of a tannery dye: From fungal screening to bioreactor application. Biochem. Eng. J. 2011, 56, 184-189. [CrossRef]

28. Pocedič, J.; Knotec, O.; Šíma, J.; Hasal, P. Rotating biological contactor and its application for decolorization of textile dyes by Irpex lacteus. Chem. Eng. Trans. 2010, 20, 67-72. 
29. Raeder, U.; Broda, P. Rapid preparation of DNA from filamentous fungi. Lett. Appl. Microbiol. 1985, 1, 17-20. [CrossRef]

30. Cassland, P.; Jönsson, L.J. Characterization of a gene encoding Trametes versicolor laccase A and improved heterologous expression in Saccharomyces cerevisiae by decreased cultivation temperature. Appl. Microbiol. Biotechnol. 1999, 52, 393-400. [CrossRef] [PubMed]

31. BLAST-Basic Local Alignment Search Tool. Available online: http://blast.ncbi.nlm.nih.gov/Blast.cgi (accessed on 7 June 2016).

32. ClustalW2. Available online: www.ebi.ac.uk/Tools/msa/clustalw2/ (accessed on 7 June 2016).

33. Chomczynski, P.; Sacchi, N. Single-step method of RNA isolation by acid guanidinium thiocyanate-phenol-chloroform extraction. Anal. Biochem. 1987, 162, 156-159. [CrossRef]

34. Imagej-1-44f. Available online: http://www.macosxfreeware.com/imagej-1-44f-scriptable-java-app-forscientific-image-processinganalysis/ (accessed on 7 June 2016).

35. Martins, M.A.M.; Lima, N.; Silvestre, A.J.D.; Queiroz, M.J. Comparative studies of fungal degradation of single or mixed bioaccessible reactive azo dyes. Chemosphere 2003, 52, 967-973. [CrossRef]

36. Kanwal, H.K.; Reddy, M.S. Effect of carbon, nitrogen sources and inducers on ligninolytic enzyme production by Morchella crassipes. World J. Microbiol. Biotechnol. 2011, 27, 687-691. [CrossRef]

37. Kumar, V.V.; Sathyaselvabala, V.; Premkumar, M.P.; Vidyadevi, T.; Sivanesan, S. Biochemical characterization of three phase partitioned laccase and its application in decolorization and degradation of synthetic dyes. J. Mol. Catal. B Enzym. 2012, 74, 63-72. [CrossRef]

38. Kachlishvili, E.; Metreveli, E.; Elisashvili, V. Modulation of Cerrena unicolor laccase and manganese peroxidase production. SpringerPlus 2014, 3, 463. [CrossRef] [PubMed]

39. Li, P.; Wang, H.L.; Liu, G.S.; Li, X.; Yao, J.M. The effect of carbon source succession on laccase activity in the co-culture process of Ganoderma lucidum and a yeast. Enzyme Microb. Technol. 2011, 48, 1-6. [CrossRef] [PubMed]

40. Pakshirajan, K.; Kheria, S. Continuous treatment of coloured industry wastewater using immobilized Phanerochaete chrysosporium in a rotating biological contactor reactor. J. Environ. Manag. 2012, 101, 118-123. [CrossRef] [PubMed]

41. Borchert, M.; Libra, J.A. Decolorization of reactive dyes by the white rot fungus Trametes versicolor in sequencing batch reactors. Biotechnol. Bioeng. 2001, 75, 313-321. [CrossRef] [PubMed]

42. Niebisch, C.H.; Malinowski, A.K.; Schadeck, R.; Mitchell, D.A.; Kava-Cordeiro, V.; Paba, J. Decolorization and biodegradation of reactive blue 220 textile dye by Lentinus crinitus extracellular extract. J. Hazard. Mater. 2010, 180, 316-322. [CrossRef] [PubMed]

43. Baldrian, P. Fungal laccases-Occurrence and properties. FEMS Microbiol. Rev. 2006, 30, 215-242. [CrossRef] [PubMed]

44. Zouari-Mechichi, H.; Mechichi, T.; Dhouib, A.; Sayadi, S.; Martínez, A.T.; Martínez, M.J. Laccase purification and characterization from, Trametes trogii isolated in, Tunisia: Decolorization of textile dyes by the purified enzyme. Enzyme Microb. Technol. 2006, 39, 141-148. [CrossRef]

45. Michniewicz, A.; Ullrich, R.; Ledakowicz, S.; Hofrichter, M. The white-rot fungus, Cerrena unicolor strain 137 produces two laccase isoforms with different physicochemical and catalytic properties. Appl. Microbiol. Biotechnol. 2006, 69, 682-688. [CrossRef] [PubMed]

46. Liu, Y.H.; Ye, M.; Lu, Y.; Zhang, X.; Li, G. Improving the decolorization for textile dyes of a metagenome-derived alkaline laccase by directed evolution. Appl. Microbiol. Biotechnol. 2011, 91, 667-675. [CrossRef] [PubMed]

47. Andriani, A.; Tachibana, S.; Itoh, K. Effects of saline-alkaline stress on benzo[a]pyrene biotransformation and ligninolytic enzyme expression by, Bjerkandera adusta, SM46. World J. Microbiol. Biotechnol. 2016, 32, 1-6. [CrossRef] [PubMed]

48. Guan, Z.B.; Song, C.M.; Zhang, N.; Zhou, W.; Xu, C.W.; Zhou, L.X.; Zhao, H.; Cai, Y.J.; Liao, X.R. Overexpression, characterization, and dye-decolorizing ability of a thermostable, pH-stable, and organic solvent-tolerant laccase from, Bacillus pumilus, W3. J. Mol. Catal. B Enzym. 2014, 101, 1-6. [CrossRef]

(C) 2016 by the authors; licensee MDPI, Basel, Switzerland. This article is an open access article distributed under the terms and conditions of the Creative Commons Attribution (CC-BY) license (http://creativecommons.org/licenses/by/4.0/). 